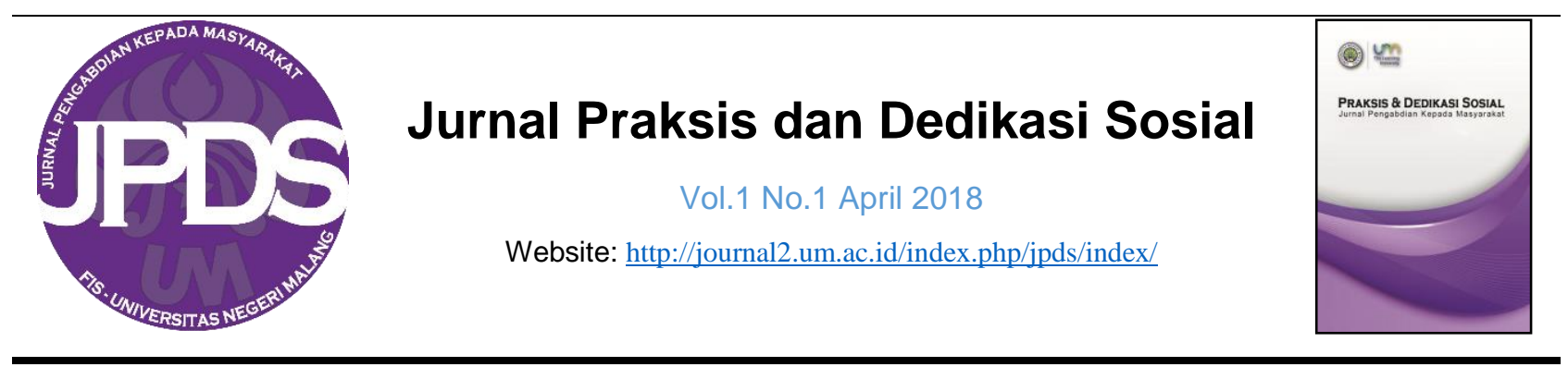

\title{
PENDIDIKAN DAN LATIHAN PENYUSUNAN PERANGKAT PEMBELAJARAN YANG MENGINTEGRASIKAN PPK BAGI GURU PPKN DI KOTA MALANG
}

\author{
Sri Untari ${ }^{1}$, Suparlan Al Hakim ${ }^{2}$ \\ 1,2Jurusan Hukum dan Kewarganegaraan, Fakultas IImu Sosial, Universitas Negeri Malang. \\ Diterima 12 Maret 2018, dipublikasikan 30 April 2018.
}

\begin{abstract}
Abstrak
Tujuan pendidikan dan pelatihan ini adalah: (1) Memberikan wawasan tentang Penguatan Pendidikan Karakter (2) Melatihkan penyusunan perangkat pembelajaran antara lain (a) analisis KI, KD dan indikator, RPP PPKn yang mengintegrasikan Penguatan Pendidikan Karakter. Metode yang dipergunakan dalam kegiatan pengabdian pada masyarakat ini. Metode partisipatif menekankan pada keikutsertaan penuh dari peserta dalam proses pelatihan, bukan metode ceramah. Peserta didorong untuk mencari, menemukan dan memperoleh pengetahuan/ketrampilan yang dibutuhkan.Pemateri menyampaikan materinya secara singkat dan dilanjutkan dialog terkait dengan implementasi materi dalam pembelajaran di kelas riil. Hasil pelaksanaan kegiatan (1) wawasan peserta tentang penguatan pendidikan karakter cukup baik, terjadi peningkatan dari hasil pre test yang rata-rata 68.5 meningkat menjadi 82.25 artinya ada peningkatan signifikan sebelum dan sesudah pelatihan; (2) peserta pelatihan dapat menganalisis KI, KD dan menyusun indikator secara baik, sehingga dapat menyusun RPP mata pelajaran yang mengintegrasikan nilai-nilai karakter utama dari PPK. Berdasarkan hasil pelaksanaan kegiatan direkomendasikan pada peserta untuk menjadikan RPP sebagai kontrak belajar yang dilaksanakan pada kelasnya. Bagi tim pelaksana perlu melaksanakan desiminasi pada sekolah lain.
\end{abstract}

\section{Kata Kunci}

Perangkat Pembelajaran, Integrasi, Penguatan Pendidikan Karakter.

(C) 2018 Penulis

PENDAHULUAN

Kurikulum tahun 2013 revisi tahun 2017 sejak awal penyusunannya telah menempatkan karakter sebagai "roh" pelaksanakaan pendididkan nilai moral di sekolah. Penguatan Pendidikan Karakter menjadi basis dalam pelaksanaan di sekolah yang dikembangkan sebagai suatu gerakan. Gerakan yang dimaksudkan bahwa pendidikan karakter harus dilakukan secara serempak bersama-sama pemerintah, sekolah dan masyarakat. PPK merupakan Program pendidikan di sekolah untuk memperkuat karakter siswa melalui harmonisasi olah hati (etik), olah rasa (estetik), olah pikir (literasi), dan olah raga (kinestetik) dengan dukungan pelibatan publik dan kerja sama antara sekolah, keluarga, dan masyarakat

${ }^{1}$ Surel korespondensi: sri.untari.fis@um.ac.id 
yang merupakan bagian dari Gerakan Nasional Revolusi Mental (GNRM) (Budhiman, 2016).

PPK dalam praktik pembelajaran di sekolah sebagai gerakan kultural kewarganegaraan (civic culture) guna mensukseskan program gerakan revolusi mental. Guru sebagai 'ujung tombak' pembelajaran menempati posisi strategis dalam mendesain dan mengelola kinerja pembelajaran yang mengintegrasikan PPK dalam pembelajaran di kelasnya. Oleh karena itu, guru profesional selain memiliki wawasan yang luas tentang PPK, juga harus mampu mengemas kegiatan pembelajaran sebagai kinerja 'kontrak' PPK dalam setiap aktivitas pembelajaran pada diri peserta didik. Dengan strategi ini, diharapkan siswa tidak verbalistis terhadap nilai karakter, melainkan dapat menjadi aktor bangsa yang memiliki komitmen tinggi dalam melaksanakan nilai-nilai utama karakter dalam kehidupan seharihari.

Berdasarkan rasional di atas, pendidikan dan latihan pembelajaran PKn yang mengintegrasikan PPK bagi guru dirasakan penting untuk dilakukan. Dengan kegiatan ini diharapkan penguatan pendidikan karakter di daerah dan di sekolah-sekolah melalui matapelajaran PKn dapat diinternalisasi sepadan dengan pemahaman peserta didik.
Tujuan kegiatan pendidikan dan latihan ini adalah: melatihkan penyusunan RPP PKn dengan mengintegrasikan Penguatan Pendidikan Karakter (PPK) melalui (a) Menentukan kompetensi dasar dan indikator yang dikembangkan dari kurikulum 2013 revisi 20017; (b) Mengintegrasikan nilai-nilai utama Karakter dalam RPP PKn; (c). Mendemonstrasikan kemampuan mengembangkan materi pokok yang sesuai dengan kompetensi; (d).Menentukan strategi pembelajaran pada setiap langkah pembelajaran pada setiap tahap (awal, inti, penutup) yang sesuai dengan kompetensi ; (e). Menyusun instrumen penilaian yang sesuai dengan indikator

\section{METODE}

Kegiatan pendidikan dan pelatihan dalam bentuk workshop dalam Penyusunan Perangkat Pembelajaran Yang Mengintegrasikan PPK Bagi Guru PPKn SMP di Kota Malang diselenggarakan selama 3 (tiga) hari tanggal 30 September-1 Oktober 2017, bertempat di SMP Sriwedari Malang. Peserta pelatihan ini sejumlah 20 orang guru PPKn SMP Sriwedari, Sang Timur, Muhammadiyah 1, Muhammadiyah 13. sm YASRI Kartini, SMP Bhakti Luhur. Bahan yang dipelukan dalam kegiatan ini antara lain: (1) Kertas plano/ flipchart buram; (2) 
Kertas Folio putih 70 gram 2 rim, (3) Kertas folio biru, kuning, dan merah masingmasing 1 rim untuk menuliskan ide peserta, khususnya untuk diskusi kelompok; (4) Spidol Whiteboard 24 biji; (5).Spidol permanent (besar) 24 biji; (6) Kertas karton biru, kuning, merah, dan hijau masingmasing 20 lembar; (7) Gunting sebanyak; (8).Cutter; (9) Kertas buffalo 2 lembar; (10) Isolasi bening besar $10 \mathrm{biji}$; (11) Selotip double-sided 10 biji (12) LCD projector.

Metode yang digunakan adalah metode partisipatif, dengan menekankan pada keikutsertaan penuh dari peserta dalam proses pelatihan, bukan metode ceramah. Peserta didorong untuk mencari, menemukan dan memperoleh pengetahuan/ketrampilan yang dibutuhkan. Pemateri berfungsi sekaligus sebagai fasilitator dengan memberikan informasi/isi materi dan memberikan rangsangan-rangsangan sebagai bahan diskusi agar peserta mampu menemukan dan memperoleh pengetahuan dan keterampilan secara konstruktivisme yang digambarkan pada gambar 1 dibawah berikut.

Keberhasilan kegiatan pelatihan ini akan dievaluasi selama proses kegiatan berlangsung sampai dengan berakhirnya kegiatan, baik yang menyangkut penguasaan materi teoritis maupun yang praktis. Adapun teknik dan sasaran evaluasi diuraikan sebagai berikut: (1) Tes penguasaan teori. Indkator meliputi: (a) pemahaman tentang apa, mengapa dan bagaimana implemntasi pendidikan penguatan karakter di sekolah melalui pembelajaran, (b) prosedur analisis $\mathrm{KI}, \mathrm{KD}$ dan indikator, tujuan (c). Hasil pemetaan KI dan KD sesuai nilai utama karakter yang akan dikembangkan, (d) pemahaman tentang komponen RPP mengintegrasikan PPK dan langkah penyusunan, (e) pemahaman tentang peran RPP mengintegrasikan PPK di sekolahnya. Kriteria keberhasilan ditetapkan inimal $75 \%$ dari banyaknya item-item soal yang dikerjakan dengan benar. (2) Penilaian unjuk kerja. Indikator penguasaan

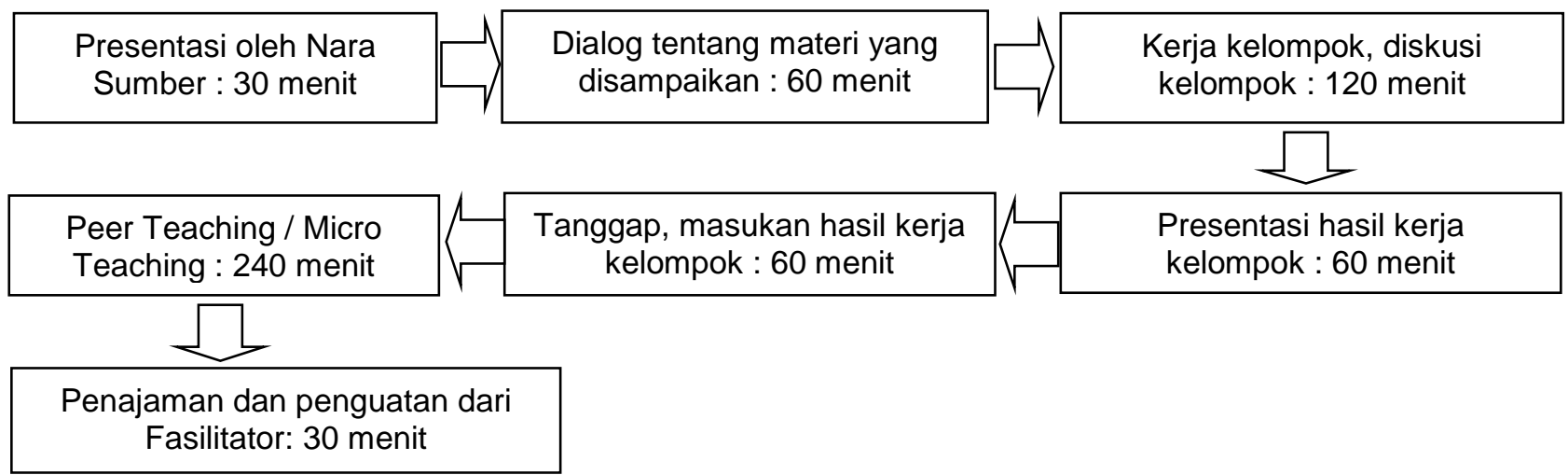

Gambar 1. Langkah kegiatan konstrustivisme. 
penerapan teori meliputi: (a) ketepatan merumuskan indikator dan tujuan (b) merumuskan tujuan dengan mengintegrasikan nilai-nilai utama karakter, (c) menyusun langkah-langkah pembelajaran yang mencerminkan nilainilai utama karakter. (d) ketepatan memilih sumber belajar (e) ketepatan menyusun penilaian.Kriteria keberhasilan unjuk kerja berupa RPP berkarakter ini $70 \%$ harus terpenuhi. (3) Evaluasi Desminasi Terbatas. Indikator meliputi; (a) aktivitas pelaksanaan, kemampuan berkomunikasi dengan sejawat, (c) kemampun kerjasama, (d) ketepatan waktu plaksanaan, (e) keberhasilan menerapkan di kelas.Kriteria keberhasilan ditetapkan $75 \%$ skor tertinggi yang dapat dicapai.Adapun kegiatan pemberdayaan lewat pelatihan pengembangan RPP berkarakter dapat dinyatakan berhasi, apabila minimal $75 \%$ dari jumah peserta mmenuhi kriteri keberhasilan yang ditetapkan sebelumnya.

\section{HASIL DAN PEMBAHASAN Hasil Kegiatan: Hasil penguasaan materi}

Hasil kegiatan menunjukkan penguasaan materi yang indikatornya meliputi: (1) pemahaman dasar pemikiran perlunya PPK; (2) pemahaman analisis $\mathrm{KI}$, KD indikator mata pelajaran PPKn sesuai kurikulum 2013 revisi ; (3) (4) pemahaman strategi mengintegrasikan nilai utama karakter PPKn, pemetaan materi dan metode pembelajaran sehingga memudahkan siswa belajar; dan (5) pemahaman dampak pengiring bagi rancangan pembelajaran PPKn yang mengintegrasikan nilai utama karakter. Pada penguasaan aspek ini, dampak kegiatan pelatihan dinyatakan "baik" , karena $70 \%$ atau lebih peserta mencapai nilai 70 ke atas, dan dinyatakan "cukup baik" jika $60 \%$ - 79\% peserta mencapai nilai kesimpulan 60 ke atas, serta dikatakan "kurang baik" jika kurang dari $50 \%$ peserta mencapai nilai kesimpulan kurang 60 , pada skala penilaian berinterval 0 sampai dengan 100.

Setelah dilakukan tes, hasilnya menunjukkan bahwa dari seluruh (20 orang) peserta pelatihan, sebanyak: 1 Orang mendapat nilai kesimpulan 50; 3 orang mendapat nilai kesimpulan 55; 4 orang mendapat nilai kesimpulan $60 ; 4$ orang mendapat nilai kesimpulan $70 ; 3$ orang mendapat nilai kesimpulan $75 ; 2$ orang mendapat nilai kesimpulan $80 ; 2$ orang mendapat nilai kesimpulan 90; dan 1 orang mendapat nilai kesimpulan 100. Jadi jumlah peserta yang mendapat nilai kesimpulan 60 ke atas adalah 17 atau $85 \%$.

\section{Hasil penguasaan penerapan teori}

Penguasaan penerapan teori dinilai berdasarkan indikator penguasaan penerapan teori meliputi: (1) ketepatan memilih nilai utama PPK; (2) perumusan 
Pendidikan dan Latihan Penyusunan Perangkat Pembelajaran...

indikator yang tepat; (3) kesesuaian merumuskan tujuan dengan indikator pencapaian kompetensi; (4) ketepatan pemilihan materi, (5) ketepatan merumuskan langkah pembelajaran yang mengintegrasikan PPK (5) ketepatan untuk menularkan hasil kegiatan pelatihan kepada teman sejawatnya tentang rancangan pembelajaran PPKn yang mengintegrasikan PPK. Kriteria keberhasilan dikatakan "baik" jika 70\% peserta pelatihan menyatakan bersedia menularkan hasil kegiatan pelatihan kepada teman-teman guru se-MGMP (untuk negeri) dan se-KOMWIL (untuk swasta); dikatakan "cukup baik" jika 50\% $69 \%$ peserta pelatihan bersedia, dan dikatakan "kurang baik" jika kurang dari $50 \%$ peserta pelatihan menyatakan bersedia.

Dari 20 orang peserta pelatihan, sebanyak 15 orang menyatakan 'sangat bersedia' menularkan hasil pelatihan; dan sisanya sebanyak 5 orang peserta pelatihan menyatakan 'bersedia' menularkan hasil kegiatan pelatihan kepada teman-teman sejawatnya. Hal ini berarti bahwa 100\% peserta pelatihan semuanya menyatakan "bersedia" menularkan hasil pelatihan kepada teman guru PPKn. Dengan demikian pada aspek ini, dampak kegiatan pelatihan dapat dikatakan berkategori baik.

\section{Hasil Diseminasi Terbatas dan Produk Pelatihan}

Evaluasi diseminasi terbatas dalam penyusunan rancangan pembelajaran PPKn dengan yang mengintegrasikan PPK dilakukan dengan kegiatan observasi (pengamatan) kinerja kelompok, yang indikatornya meliputi: (1) aktivitas pelaksanaan; (2) kemampuan berkomunikasi dengan sejawat; kemampuan kerjasama; dan (4) ketepatan waktu pelaksanaan/penyerahan produk. Dari hasil observasi pada umumnya peserta pelatihan melakukan dengan baik. Hanya saja, pada saat penyerahan produk, dari lima kelompok (topik), diketahui tiga kelompok menyerahkan tepat waku dan dua kelompok sisanya mengalami keterlambatan dalam menyerahkannnya. Setelah dilakukan konfirmasi, keterlambatan mereka disebabkan oleh faktor kesibukan anggota kelompok.

\section{Pembahasan}

Wawasan guru tentang PPK perlu terus dikembangkan demi suksesnya Gerakan Revolusi Mental yang dicanangkan Presiden Jokowi. Pada pemerintahan Presiden Jokowi-Yusuf Kalla Penguatan karakter menjadi salah satu program prioritas yang merupakan implementasi dari nawa cita. Dalam Nawa Cita disebutkan bahwa pemerintah akan melakukan revolusi karakter bangsa. Implementasi dari kebijakan tersebut dilaksanakan Kementerian Pendidikan dan 
Kebudayaan dalam wujud penguatan karakter penerus bangsa melalui gerakan Penguatan Pendidikan Karakter (PPK) yang digulirkan sejak tahun 2016 (Kemendikbud, 2017).

Kinerja guru dalam pelaksanaan pembeajaran menjadi suatu keharusan untuk mengintegrasikan lima (5) nilai karakter utama dalam penyusunan perangkat pembelajaran, untuk itu pemahaman guru tentang Penguatan Pendidikan Karakter yang selanjutnya disingkat PPK menjadi sangat urgen. Terlebih dengan diberlakunya kurikulum 2013 revisi tahun 2017, PPK merupakan yang urgen, sebagaimana dikemukakan Budhiman (2016) yang menyatakan bahwa PPK diperlukan dalam rangka pembangunan SDM merupakan pondasi pembangunan bangsa; dalammenuju Generasi Emas 2045 dengan dibekali Keterampilan abad 21 yakni : Kualitas Karakter, Literasi Dasar, dan Kompetensi 4C. dan Kecenderungan kondisi degradasi moralitas, etika, dan budi pekerti.

PPK perlu diinformasikan kepada guru, agar mereka mampu menemukan strategi yang tepat dalam menginternalisasi nilai karakter melalui pembelajaran di kelasnya. Menurut Kama (2016) bahwa proses internalisasi nilai itu dengan : Informasi moral (Moral information level); Keyakinan moral (Moral belief level); Sikap moral (Moral Attitude level); Nilai moral (Moral value level); Karakter/kepribadian moral (Moral character/personality level); Jati diri bermoral (Moral dignity level). Untuk itu keterampilan guru dalam menyusun perangkat pembelajaran utamanya Rencana Pelaksanaan Pembelajaran (RPP) yang mengintegrasikan nilai-nilai karakter harus terus ditingkatkan, sehingga guru secara tepat dapat memilah dan memilih nilai karakter utama mana yang tepat untuk diinternalisasikan dalam KI, KD yang akan dibelajarkan pada peserta didiknya (Untari, 2017; Nurdin, 2016).

Penyusunan

RPP yang mengintegrasikan nilai karakter yang dilatihkan pada kegiatan pengabdian pada masyarakat pada hakekatnya adalah mengembangkan keterampilan guru PPKn SMP di Kota Malang untuk secara teoritik menguatkan wawasannya tentang komponen karakter yang baik yang harus terus dikuatkan, sebagaimana dikemukakan oleh Lickona (1986) bahwa komponen karakter yang baik yang dapat digambarkan pada gambar 2 dibawah berikut. 


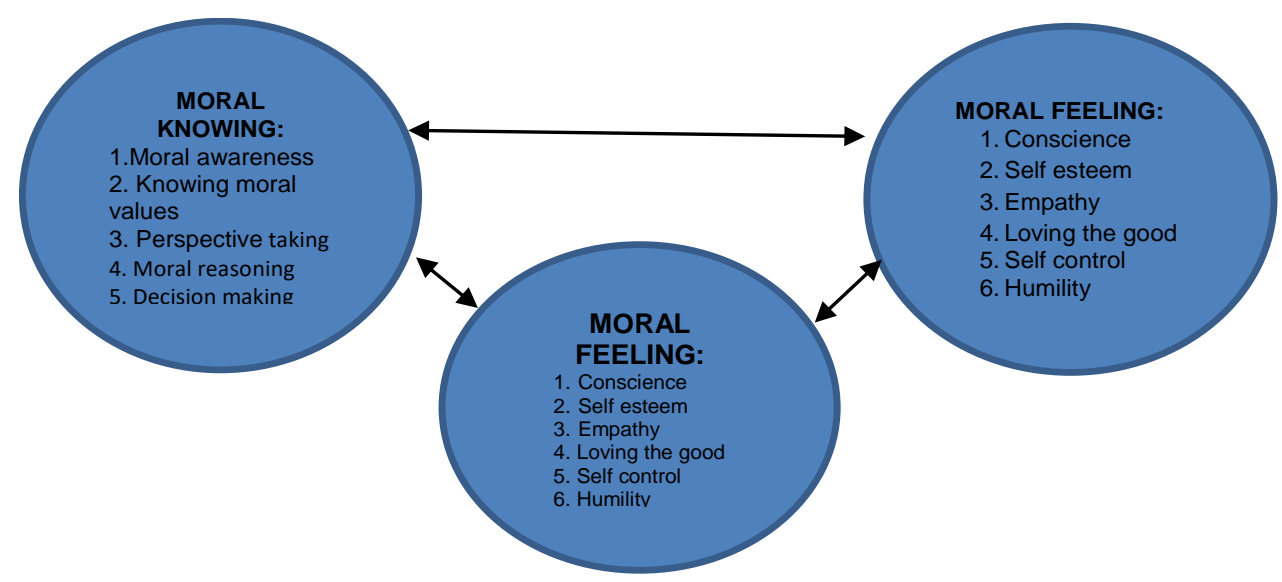

Gambar 2. Komponen Karakter (Nurdin Encep Syarief, 2016)

Komponen karakter yang demikian perlu terus disinkronkan dan diintegrasikan dalam penyelenggarakan pendidikan dan diintegrasikan dalam pembelajaran di kelas. Duska et al. (1975). Produk RPP yang mengintegrasikan nilai-nilai karakter hasil pelatihan yang dibuat oleh guru PPkn SMP senyatanya bermanfaat bagi peserta didik dan sekolah, sesuai tulisan Budhiman (2016) bahwa salah satu manfaat PPK adalah pembelajaran dilakukan terintegrasi di sekolah dan di luar sekolah dengan pengawasan guru.

\section{Hambatan dan Upaya Mengatasi Hambatan Hambatan}

Kegiatan pelatihan ada banyak hambatan yakni (1) perbedaan persepsi tentang integrasi nilai karakter utama. Pada awalnya peserta memiliki pandangan bahwa dalam RPP harus mencantumkan lima nilai utama karakter, sebagian perpandangan nilai utama bisa dipilih satu atau dua sesuai $\mathrm{KI}, \mathrm{KD}$ dan materi yang dibelajarkan pada peserta didik. (2) peserta mengalami kesulitan dalam menyusun instrumen penilaian, mengingat dalam PPK ada paradigma yang berbeda dengan penilaian pembelajaran yang dilakukan guru selama ini, yang diukur dari nilai yang diperoleh melalui tes.

\section{Upaya Mengatasi Hambatan.}

Upaya yang ditempuh dalam mengatasi hambatan (1) perbedaan persepsi tentang pemilihan atau penetapan nilai karakter utama dilakukan diskusi dan dialog mendalam, sehingga menemukan kesepakan bahwa mengintegrasi nilai karakter dipilih sesuai dengan KI,KD dan materi pelajaran, tidak mencantumkan semua nilai karakter utama. Juga disepakati guru dapat menjabarkan nilai karakter utama dengan sub nilai yang tepat. (2) dilatihkan pada guru untuk mengembangkan rubric penilaian, dimana paradigma penilaian hakekatnya berbasis pada reward bukan punishment, sehingga manakala siswa belum nampak melakukan perilaku sesuai dengan nilai yang diinternalisasikan, 
peserta didik tetap mendapat dinilai baik.sebagaimana dituliskan Untari(2016) menyatakan bahwa pendekatan positif menerapkan nilai-nilai luhur bangsa atau nilai karakter dipergunakan agar peserta didik memiliki semangat dan motivasi untuk senantiasa berbuat baik setiap saat, bukan karena nilai yang bersifat kuantitatif.

\section{KESIMPULAN}

Kemampuan membuat perangkat pembelajaran PPKn dengan mengintegrasikan nilai-nilai karakter utama, yang meliputi aspek (1) menganalisis $\mathrm{KI}, \mathrm{KD}$ dan indiktor pencapaian kompetensi dan pemilihan nilai karakter utama; (2) analisis materi pembelajaran; (3) organisasi materi pembelajaran; (4) merumuskan langkahlangkah pembelajarana; (4) penetapan teknik evaluasi yang bernuansa PPK; dan (5) produk rencana pelaksanaan pembelajaran PPKn yang mengintegrasikan PPK dapat disimpulkan sebagai berikut.

Pertama, penguasaan materi pelatihan pengembangkan RPP PPKn dengan mengintegrasikan PPK, dapat disimpulkan bahwa dari seluruh (20 orang) peserta pelatihan, sebanyak: 1 Orang mendapat nilai kesimpulan 50; 3 orang mendapat nilai kesimpulan 55; 4 orang mendapat nilai kesimpulan 60; 4 orang mendapat nilai kesimpulan 70; 3 orang mendapat nilai kesimpulan 75; 2 orang mendapat nilai kesimpulan 80; 2 orang mendapat nilai kesimpulan 90; dan 1 orang mendapat nilai kesimpulan 100. Jadi jumlah peserta yang mendapat nilai kesimpulan 60 ke atas adalah 17 atau $85 \%$.

Kedua, hasil penguasaan dan kesediaan penerapan teori, dari 20 orang peserta pelatihan, sebanyak 15 orang menyatakan 'sangat bersedia' menularkan hasil pelatihan; dan sisanya sebanyak 5 orang peserta pelatihan menyatakan 'bersedia' menularkan hasil kegiatan pelatihan kepada teman-teman sejawatnya. Hal ini berarti bahwa 100\% peserta pelatihan semuanya menyatakan "bersedia" menularkan hasil pelatihan kepada teman guru PPKn. Dengan demikian pada aspek ini, dampak kegiatan pelatihan dapat dikatakan berkategori baik.

Ketiga, evaluasi deseminasi terbatas dalam pembuatan perangkat pembelajaran PPKn dengan mengintegrasikan PPK dilakukan dengan kegiatan observasi (pengamatan) kinerja kelompok, yang indikatornya meliputi: (1) aktivitas pelaksanaan;

(2) kemampuan berkomunikasi dengan sejawat; (3) kemampuan kerjasama; dan (4) ketepatan waktu pelaksanaan/penyerahan produk. Dari hasil observasi pada umumnya peserta pelatihan melakukan dengan baik. Hanya saja, pada saat penyerahan produk, dari lima kelompok (topik), diketahui tiga 
Pendidikan dan Latihan Penyusunan Perangkat Pembelajaran...

kelompok menyerahkan tepat waku dan dua kelompok sisanya mengalami keterlambatan dalam menyerahkannnya. Setelah dilakukan konfirmasi, keterlambatan mereka disebabkan oleh faktor kesibukan anggota kelompok 4. Sampai dengan berakhirnya pelatihan peserta telah menghasilkan lima RPP dengan mengintegrasikan nilai-nilai karakter.

\section{Saran}

Berdasarkan hasil diskusi selama kegiatan pendidikan dan pelatihan penyusunan perangkat pembelajaran yang mengintegrasikan PPK berlangsung, ratarata guru belum memiliki kemampuan yang memadai dalam menganalisis kompetensi inti dan kompetensi dasar, dan merumuskan indikator pencapaian kompetensi, penyusunan RPP yang mengintegrasikan nilai karakter utama dalam PPK. Untuk itu disarankan agar ada materi yang bersifat penunjang dalam implementasi PPK dalam pembelajaran, yang memberikan pelatihan guru untuk membuat dan mengembangkan pembelajaran yang mengintegrasikan PPK.

\section{DAFTAR RUJUKAN}

Budhiman, A. 2016. Penguatan Pendidikan Karakter Melalui Gerakan penumbuhan Pekerti. Jakarta. Kementerian Penddikan dan Kebudayaan.bidang Pembangunan Karakter.

Duska et al. 1975. Moral Development. A Guide to Piaget and Kohlberg, New York: Paulist Press.

Kama. 2016. Strategi Gerakan Penumbuhan Budi Pekerti.Direktorat Pembinaan Sekolah Dasar. Jakarta. Direktorat Pembinaan Sekolah Dasar.

Kementerian Pendidikan dan Kebudayaan.2017. Penguatan Pendidikan Karakter Jadi Pintu Masuk Pembenahan Pendidikan Nasional $\quad 17 \quad$ Juli 2017. https://www.kemdikbud.go.id/main/bl og/2017/07/penguatan-pendidikankarakter-jadi-pintu-masukpembenahan-pendidikan-nasional diakses 11 maret 2018

Lickona, T. 1989. Educating for Character: How Our Schools Can Teach Respect and Responsibility, New York: The New York Times Company. Nurdin, E.C. 2016. Konsep Dasar Gerakan Penumbuhan Budi Pekerti. Jakarta. Direktorat Pembinaan Sekolah Dasar.

Untari. Sri. 2017. Evaluasi kegiatan Gerakan Penumbuhan Budi Pekerti. Jakarta. Direktorat Pembinaan Sekolah Dasar. 